\title{
PRODUKSI KOSAKATA ANAK MELALUI ELECTRONIC WORDLESS PICTURE STORYBOOK
}

\author{
Nurul Arifiyanti dan Kartika Ananda \\ Pendidikan Anak Usia Dini, Pascasarjana Universitas Negeri Yogy akarta \\ Jalan Colombo No. 1, Karang Malang, Sleman, Daerah Istimewa Yogyakarta, 55281 \\ Surel: nurularifiy@gmail.com
}

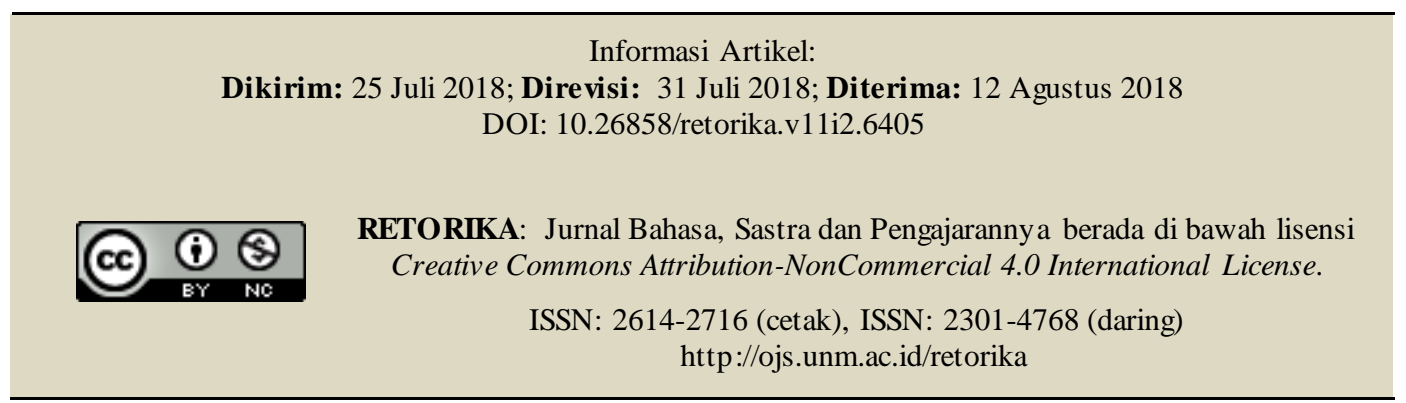

\begin{abstract}
Children's Vocabulary Production through Electronics Wordless Picture Storybook. This study aims to reveal the effectiveness of the use of electronic wordless picture storybook to improve the production of children's vocabulary. We compared a printed wordless story book and an electronic wordless storybook. The quasi-experiment research with one group posttest design only was used in this study. The subjects were six teachers and 59 children aged 24-48 months. Samples were taken using a saturated sample technique in three early childhood educational institutions. The instrument used was an observation sheet. The data were then analyzed using the Mann Whitney Test. The result was an electronic wordless picture storybook more effecttive to produce children's vocabulary.
\end{abstract}

\begin{abstract}
Abstrak: Produksi Kosakata Anak Melalui Electronic Wordless Picture Storybook. Penelitian ini bertujuan untuk mengungkapkan keefektivan penggunaan electronic wordless picture storybook dalam produksi kosakata anak. Studi ini membandingkan buku cerita tanpa yang dicetak dan buku cerita tanpa kata elektronik. Jenis penelitian ini adalah penelitian eksperimen semu (quasy experiment) dengan one group postest design only. Subyek pada penelitian ini adalah enam guru dan 59 anak berusia 24-48 bulan. Sampel diambil menggunakan teknik sampel jenuh di tiga lembaga pendidikan anak usia dini. Instrumen yang digunakan adalah lembar observasi. Data kemudian dianalisis menggunakan Tes Mann Whitney. Hasilnya buku cerita tanpa kata elektronik lebih efektif untuk menghasilkan kosakata anak-anak.
\end{abstract}

Kata kunci: anak usia dini, kosakata, electronic wordless picture storybook 
Stimulasi perkembangan bahasa selama masa prasekolah dapat mendukung kesuksesan kemampuan membaca anak di masa berikutnya (Whorrall dan Cabell, 2016). Stimulasi lingkungan dapat diberikan baik oleh orang tua, guru, atau teman sebaya ketika anak mengikuti layanan pendidikan anak usia dini (PAUD). Melalui interaksi sosial, anak akan belajar untuk memahami bahasa yang ia dengar. Lebih jauh, ia juga belajar menyusun kata agar dapat dimengerti oleh orang lain. Dengan demikian, seiring berjalannya waktu, kosakata anak akan bertambah melalui pengalaman sosialnya.

Sebagai pihak yang bertanggung jawab ketika anak di PAUD, guru harus mendorong intensitas percakapan dengan anak (Cabell, Justice, McGinty, DeCoster, dan Forston, 2015). Kosakata anak akan terus bertambah ketika guru menerapkan stimulasi perkembangan bahasa. Kegiatan yang menyenangkan, seperti membaca buku cerita mendorong anak untuk menambah berbagai kosakata baru. Ketika anak sudah memahami setiap kata yang ada di buku, ia dapat mengulang apa yang ada di dalam pikirannya. Sebaliknya, ketika ia belum tahu makna dari dari suatu kata dalam buku, ia akan mendengarkan dan mencatat ke dalam pikirannya kata baru tersebut. Selama masa kanak-kanak, kemampuan produksi kata harus terus dikembangkan untuk membantu anak berinteraksi dengan orang lain, menginterpretasikan komunikasi, dan menyampaikan apa yang sedang ia pikirkan. Beberapa penelitian terdahulu menemukan bahwa buku bergambar dapat mendukung anak usia dini dalam mengembangkan kosa kata, serta mengembangkan tindakan dan mental mereka. Selain itu, buku bergambar juga berfungsi untuk merangsang minat anak usia dini dalam menginduksi proses membaca (Newton, 1992). Buku cerita bergambar mendorong pemahaman anak tentang bahasa, mengembangakan rasa ingin tahu dan pertanyaan-pertanyaan anak, serta mendukung pembangunan pengetahuan baru bagi anak (Torr \& Clugston, 2006). Lebih jauh, membaca dengan buku bergambar juga memberi banyak kesempatan bagi keluarga untuk membangun kegembiraan dan hubungan pengalaman keaksaraan bagi anak usia dini (Montgomery \& Smith, 2014). Buku cerita dapat mengembangkan imajinasi dan membantu anak belajar tentang nilai atau nasihat yang terkandung dalam suatu buku cerita.

Hasil penelitian yang dilakukan oleh Chparro-Moreno, Reali, dan Maldonado-Carreno
(2017) menunjukan bahwa buku bergambar tanpa teks (wordless picture book) lebih efektif dalam menstimulasi produksi kosakata anak. Buku cerita bergambar tanpa teks menyajikan berbagai gambar yang sesuai isi cerita namun tidak menambahkan kalimat alur atau isi cerita dalam bentuk tulisan. Buku ini dapat dijadikan sebagai stimulasi kosakata anak usia 2-4 tahun dengan cara menanyakan kepada anak kegiatan yang sedang dilakukan tokoh dalam buku. Kreativitas anak dalam memproduksi kosakata akan terstimulasi dengan baik ketika menggunakan buku ini.

Kemampuan anak dalam memproduksi kosakata baru merupakan bentuk keberhasilan anak dalam memahami dan menanggapi bahasa. Chparro-Moreno, Reali, dan Maldonado-Carreno (2017) menyebutkan beberapa indikator terkait produksi kata pada anak usia dini yang penting untuk dikembangkan, yakni jumlah kata, keragaman leksikal (jumlah jenis kata), dan jumlah total ucapan (unit-unit ). Jumlah kosakata pada anak usia 2-3 tahun rata-rata dapat menggunakan 900-1.000 kata (Papalia, 2001). Keanekaragaman kata yang diucapkan anak biasanya digunakan sebagai ukuran kekayaan kosakata. Kekayaan kosakata dapat dilihat dari jenis kata, seperti kata kerja, kata sifat, dan kata benda.

Seiring perkembangan zaman dan teknologi, buku diterbitkan dalam bentuk digital atau elektronik dengan tampilan yang menarik dan mudah dibawa (Evans., Nowak, Burek, dan Willoughby, 2017). Beberapa buku elektronik bahkan ada yang memberikan suara tentang cara mengucapkan ejaan yang benar. Secara umum, buku elektronik bisa disebut sebagai electronic book, e-book, eBook, e-Book, ebook, digital book, atau bahkan e-edition (Prasetya \& Tsukasa, 2018). Buku elektronik lebih banyak diminati karena bersifat praktis untuk dibawa ke mana saja. Selain itu, buku elektronik biasanya memiliki fitur untuk melakukan pencarian sehingga kata-kata dalam buku tersebut mudah ditemukan (Widodo, 2016).

Keefektivan penggunaan buku elektronik telah diteliti oleh Korat dan Shamir (2012) yang menyatakan bahwa anak yang membaca buku elektronik menunjukkan kemajuan yang lebih baik dalam pemahaman kosakata dibandingkan dengan yang menggunakan buku cetak. Lebih lanjut, Korat dan Blau (2010) juga membuktikan bahwa anak yang membaca buku elektronik sebanyak lima kali menunjukkan kemajuan yang 
lebih baik dalam kesadaran fonologis (kemampuan anak dalam mendeteksi dan memanipulasi bunyi) dibandingkan dengan anak yang membaca buku tersbut sebanyak tiga kali saja. Penggunaan media elektronik dalam pembelajaran di sekolah juga dapat memberikan variasi suasana belajar yang mungkin selama ini masih konvensional. Sifat anak usia dini yang mudah bosan mendorong guru harus ters berinovasi dalam penggunaan media pembelajaran.

Buku elektronik dapat mendorong minat anak untuk membaca sehingga nilai-nilai yang terkandung dalam cerita tersebut mampu mengurangi perilaku negatifnya (Ciampa, 2012). Penelitian tersebut menunjukkan jika online reading software, motivasi, dan metode pembelajaran konstrustivistik dapat mendorong anak untuk suka membaca sejak dini. Lebih jauh, diungkapkan bahwa media ini juga dapat meningkatkan anak untuk menyelesaikan tugas, meningkatkan perhatian, dan mengembangkan kompetensinya. Banyak manfaat yang akan didapatkan ketika membaca menggunakan buku elektronik.

Anak sangat antusias ketika diberikan buku cerita elektronik meskipun tanpa dukungan dari guru (Prasetya dan Tsukasa, 2018). Penggunaan berbagai elemen media seperti, teks, gambar, dan warna dalam buku cerita elektronik menciptakan media yang edukatif dan menarik bagi anak. Media ini dapat menjadi solusi praktis untuk meningkatkan pengetahuan dan penanaman nilai-nilai karakter tokoh cerita pada anak prasekolah. Alur cerita yang sederhana dengan mengusung tema kehidupan sehari-hari memudahkan anak untuk memahami isi cerita yang disampaikan.

Penelitian sebelumnya telah menunjukkan bahwa membaca buku cerita dengan orang dewasa dapat meningkatkan jumlah kosakata anak-anak prasekolah. Namun demikian, hanya sedikit penelitian yang membahas peran potensial buku cerita tanpa kata, terutama penggunaan buku elektronik. Oleh karena itu, fokus penelitian ini adalah membandingkan pengaruh buku cerita tanpa teks cetak dan elektronik terhadap produksi kata anak usia 3-4 tahun. Hasil penelitian diharapkan akan memberikan dampak pada proses stimulasi perkembangan bahasa di PAUD. Pengenalan teknologi kepada anak melalui kegiatan membaca dapat memotivasi mereka untuk memproduksi kosakata lebih banyak. Anak akan menghubungkan teknologi yang digunakan, seperti laptop dengan pengalaman yang mereka temui ketika di tempat lain. Hal ini akan mendorong anak menghasilkan lebih banyak produksi kosakata dikarenakan mereka menghubungkan perihal yang dilihat sekarang dengan pengalaman masa lalu yang ditunjukkan dengan kosakata yang terus diucapkan.

\section{METODE}

Jenis penelitian ini adalah penelitian eksperimen semu (quasy experiment) dengan design one group postest design only. Subjek pada penelitian ini adalah guru dan anak prasekolah di tiga lembaga pendidikan anak usia dini, yakni (1) KB AnakQu, (2), KB Dharma Yoga Santi, dan (3) SPS Mutiara Hati. Prasekolah ini dipilih karena lokasi berada di daerah kota sehingga mendapat kemudahan terhadap akses teknologi. Teknik pengambilan sampel menggunakan sampel jenuh. Semua populasi digunakan dalam penelitian. Enam guru berjenis kelamin perempuan menjadi sampel penelitian. Mereka memiliki pengalaman mengajar antara 5-8 tahun $(\mathrm{M}=6,16, \mathrm{SD}=1,34)$. Guru yang menjadi sampel memiliki tingkat pendidikan yang beragam. Semuanya bergelar gelar sarjana. Rerata usia mereka 29 tahun. Anak yang menjadi subjek penelitian sebanyak 59 orang yang berusia $36-48$ bulan. Sebanyak 31 orang anak berjenis kelamin perempuan dan 29 anak berjenis kelamin laki-laki. Semua anak diikutsertakan dalam penelitian ini tanpa adanya diagnosis kesulitan belajar atau kognitif. Rata-rata perbandingan guru dan anak adalah 1 orang dewasa dibanding 10 anak. Anak menggunakan bahasa Indonesia sebagai bahasa utama mereka. Sebanyak 2 anak menggunakan bahasa tradisional, yaitu Jawa dan satu anak menggunakan bahasa Inggris ketika di rumah.

Semua produksi kosakata anak direkam dalam sebuah video kemudian ditranskrip dalam sebuah file. Instrumen observasi produksi kata diadaptasi dari penelitian Chaparro-moreno, Reali, dan Maldonado-carre (2017) dengan indikator: (a) jenis kata (kata benda, kata kerja, kata sifat, kata keterangan, dan tanda tanya), jumlah kata perhalaman, dan jumlah total kata dalam satu buku. Jumlah produksi kosakata anak dimasukkan dalam lembar observasi lalu dianalisis.

Penelitian dilakukan pada September 2017 sampai Februari 2018. Sesi membaca buku terbagi menjadi dua sesi, yaitu menggunakan model klasikal dan kelompok berdasarkan gender. Pro- 
ses yang dilaksanakan mencakup: (1) guru dan anak membaca buku cerita tanpa teks secara bersama dalam 6 kali uji coba, (2) anak membaca buku cerita tanpa teks secara kelompok (kelompok dibagi dua, yakni laki-laki dan perempuan) dalam 12 kali ujicoba. Guru mengajak untuk membaca dua buku secara eksperimen dengan menggunakan pendekatan bebas (teacher centered or student center) pada dua sesi yang berbeda, yaitu sesi membaca printed wordless picture storybook dan electronic wordless picture storybook.

Buku yang digunakan adalah Paus Beluga oleh Yeniar (2017) sebagai buku cetak yang telah diedit sehingga ditampilkan dalam bentuk tanpa teks dan Anjing dan Kelinci yang diterbitkan oleh Kementerian Keuangan Republik Indonesia, Direktorat Jenderal Pajak, Direkur Penyuluhan, Pelayanan, dan Hubungan Masyarakat (2014) sebagai media elektronik. Electronic wordless storybook ditampilkan melalui layar komputer yang digunakan anak secara bersamaan dan dalam kelompok sesuai gendernya. Sebelumnya, guru dan anak dipastikan belum mengenal buku yang dipilih dalam penelitian ini. Buku yang digunakan adalah buku cerita tanpa teks. Karakter utama disusun melalui berbagai adegan.

Buku yang dipilih memiliki karakteristik sama, yakni memiliki 9 halaman, bertema hewan, memiliki ukuran dan bentuk gambar seukuran kertas ukuran folio, dan gaya ilustrasi yang menarik. Kedua buku tersebut bercerita tentang hewan dan keduanya menyajikan alur cerita yang tokoh utamanya menghadapi masalah dan menyelesaikannya bersama teman-temannya. Dalam buku cerita tanpa teks cetak, karakter utama (lumba-lumba) menguraikan sebuah rencana dengan teman-temannya untuk menolong ikan-ikan kecil yang ditangkap menggunakan racun oleh pencuri ikan. Rencana mereka melibatkan seorang polisi laut. Dalam buku cerita tanpa teks elektronik, tokoh utama adalah seekor kelinci yang dibantu temannya untuk meminta maaf kepada anjing karena telah mencuri tanaman wortel yang dijaga oleh anjing. Nilai yang terkandung dalam dua buku cerita ini sebanding, keduanya bercerita tentang kebersamaan dan menolong sesama. Dalam kasus buku cerita tanpa teks cetak, lumba-lumba dibantu teman-temannya untuk menolong ikan-ikan kecil. Dalam kasus buku cerita tanpa teks elektronik, kelinci juga dibantu temannya untuk meminta maaf kepada anjing.
Data yang telah terkumpul dianalisis dengan bantuan program SPSS 16.00 for windows. Analisis pertama dilakukan melalui uji normalitas dan homogenitas. Setelah mengetahui normalitas dan homogenitasnya, data dites menggunakan uji beda untuk menentukan jenis statistik yang digunakan: parametrik atau nonparametric. Uji statistik digulakukan untuk menjawab hipotesis penelitian, yakni terdapat perbedaan produksi kosakata anak ketika menggunakan printed wordless picture storybook dan electronic wordless picture storybook.

\section{HASIL DAN PEMBAHASAN}

Hasil penelitian dijabarkan melalui paparan berikut. Tabel 1 . menunjukkan hasil uji normalitas.

\begin{tabular}{lcl} 
Table & 1. Ringkasan Hasil Uji Normalitas \\
\hline Variabel & $\begin{array}{c}\text { Nilai Asymp. } \\
\text { Sig. }\end{array}$ & Sebaran \\
\hline Buku Cetak & 0,683 & Normal \\
\hline Buku Elektronik & 0,819 & Normal \\
\hline
\end{tabular}

Berdasarkan Tabel 1, dapat diketahui bahwa data yang diperoleh dari hasil penelitian memiliki asumsi normal dengan nilai Asymp. Sig. 0,638 dan $0,819>0,05$. Oleh karena itu, uji prasyarat pertama untuk uji statistik parametris terpenuhi. Setelah uji normalitas, langkah selanjutnya adalah menguji homogenitas data. Hasil uji homogenitas ditunjukkan melalui Tabel 2. Produksi kosakata anak juga diuraikan berdasarkan kelas kata.

Table 2. Ringkasan Hasil Uji Homogenitas

\begin{tabular}{lcccc}
\hline Levene Statistic & Df1 & Df2 & Sig \\
\hline 30.005 & 1 & 116 & 0.00 \\
\hline
\end{tabular}

Berdasarkan Tabel 2. dapat diketahui bahwa data yang diperoleh dari hasil penelitian memiliki asumsi tidak homogen karena nilai Sig. $0,00<0,05$. Oleh karena itu, uji prasyarat kedua untuk uji statistik parametris tidak terpenuhi. Oleh karena itu, analisis data dilakukan dengan menggunakan uji nonparametric ,yaitu uji Mann Whitney test. Tabel 3 menunjukkan hasil dari uji tersebut. 
Table 3. Hasil Uji Mann Whitney test

\begin{tabular}{cccc}
\hline & $\begin{array}{c}\text { Mann- } \\
\text { Whitney U }\end{array}$ & $\mathbf{Z}$ & $\begin{array}{c}\text { Nilai } \\
\text { Asymp.Sig. }\end{array}$ \\
\hline $\begin{array}{c}\text { Test } \\
\text { Statistics }\end{array}$ & 253.500 & -8.006 & 0.00 \\
\hline
\end{tabular}

Berdasarkan Tabel 3, penggunaan buku cerita tanpa teks cetak dan elektronik menunjukkan adanya perbedaan dalam dalam memproduksi kosakata anak $(\mathrm{p}<0,05)$. Skor rata-rata penggunaan buku cerita tanpa teks elektronik adalah 52,25. Nilai rata-rata itu lebih tinggi dibanding penggunaan buku cerita tanpa teks cetak yang hanya memperoleh skor rata-rata sebesar 22,25

Analisis deskriptif dilakukan untuk mengungkap hasil produksi kosakata anak. Hasil analisis produksi kosakata anak ditunjukkan pada Tabel 4. Produksi kosakata juga dianalisis berdasarkan jenis kata. Tabel 5 rerata kosakata anak berdasarkan jenis kata yang diucapkan.

Table 4. Deskripsi Hasil Produksi Kosakata Anak

\begin{tabular}{cccc}
\hline Variabel & Mean & $\begin{array}{c}\text { Jumlah } \\
\text { Minimum }\end{array}$ & $\begin{array}{c}\text { Jumlah } \\
\text { Maksimum }\end{array}$ \\
\hline Buku Cetak & 22,25 & 10 & 53 \\
\hline Buku Elektronik & 52,25 & 14 & 98 \\
\hline
\end{tabular}

Table 5. Skor Rerata Produksi Kosatakata Anak

\begin{tabular}{lcc}
\hline \multicolumn{1}{c}{ Aspek } & Cetak & Elektronik \\
\hline Jumlah kata & 2 & 2 \\
perhalaman & 3 & 3 \\
Kata Benda & 4 & 3 \\
Kata Kerja & 2 & 2 \\
Kata Sifat & 6 & 9 \\
Kata Keterangan & 1 & 1 \\
Kata Tanya & & \\
\hline
\end{tabular}

Secara keseluruhan, hasil penelitian menunjukkan bahwa buku cerita tanpa teks elektronik lebih efektif dalam meningkatkan produksi kosakata anak. Metode pembelajaran yang berbeda dari guru ketika menggunakan printed dan electronic wordless picture book melatarbelakangi perbedaan hasil belajar. Kehati-hatian guru ketika anak menggunakan laptop menjadi salah satu faktor terjadinya tanya jawab lebih lanjut. $\mathrm{Hal}$ ini tentu berbeda ketika menggunakan printed book yang memberikan kesempatan kepada anak menggunakannya tanpa pengawasan.

\section{Pembahasan}

Tujuan utama dari penelitian ini adalah untuk mengetahui pengaruh penggunaan electro- nic wordless picture book pada produksi kosa kata anak usia 2-4. Hasil penelitian menunjukkan bahwa menggunakan electronic wordless picture book lebih efektif meningkatkan produksi kosakata anak. Indikator yang digunakan sebagai parameter terdiri atas jumlah kata per halaman dan jumlah jenis kata (kata benda, kata kerja, kata sifat, kata keterangan, dan kata tanya). Tingginya tingkat produksi kosakata anak, konsentrasi serta minat anak mencerminkan tingkat dukungan instruksional guru ketika menggunakan electronic wordless picture book. Secara keseluruhan, hasil ini konsisten dengan penelitian yang menunjukkan bahwa buku elektronik menarik perhatian anak dan merangsang imajinasi mereka (Matthew, 2015)

Penelitian ini adalah penelitian pertama yang secara langsung dan detail membandingkan pengaruh dari electronic wordless picture book terhadap produksi kosakata anak yang dinilai dari setiap halaman buku cerita dan dari jenis kata yang dihasilkan anak. Conrad dan Tracy (2016) menyatakan tidak ada perbedaan signifikan dalam perbaikan kosa kata dan motivasi anak dalam kelas kontrol yang menggunakan media cetak dengan kelas eksperimen yang menggunakan media elektronik. Akan tetapi, melalui penelitian ini ditemukan adanya perbedaan siginifikan antara penggunaan media cetak dan dengan media elektronik. Menggunakan electronic wordless picture book menghasilkan tingkat kualitas yang lebih tinggi dalam memproduksi kosa kata anak bila dibandingkan dengan buku cerita tanpa teks cetak. Penggunaan buku cerita elektronik tampaknya terkait dengan minat, suasana belajar, dan dukungan pengajaran dari guru sehingga anak menghasilkan lebih banyak kosakata.

Anak terlihat antusias ketika menggunakan printed wordless picture book. Gambar yang penuh warna, dengan tokoh kartun binatang, dan berukuran A3 menarik motivasi dan minat anak untuk mengikuti kegiatan membaca. Akan tetapi, setelah selesai membaca bersama, anak terlihat tidak lagi termotivasi untuk membuka buku cerita cerak tersebut. Buku cetak yang sudah biasa dilihat anak memungkinkan mereka tidak begitu tertarik lagi untuk membaca buku tersebut. Hal ini berbeda dengan ketika guru menggunakan media elektronik. Anak masih terlihat menunggu antrean, bahkan sampai berebut untuk bisa membaca cerita yang disajikan meskipun kegiatan membaca bersama telah selesai. Suasana belajar 
yang baru dengan menghadirkan buku elektronik mampu menggugah minat baca anak.

Ketika menggunakan electronic wordless picture book, guru maupun orang dewasa melibatkan anak dalam proses kreatif, mendorong partisipasi melalui tanya jawab dan umpan balik melalui ilustrasi gambar yang disajikan di dalam buku. Anak-anak yang membaca buku cerita elektronik dengan bantuan dan dukungan orang dewasa dapat mendorong kemajuan dalam kesadaran fonologis dan pembendaharaan katanya (Korat dan Segaldrori, 2016). Secara umum, tanda-tanda visual (seperti gambar) dapat menghasilkan interpretasi yang berbeda dari masingmasing anak. Dalam kondisi ini, anak-anak didorong untuk membangun cerita bersama melalui strategi, seperti pertanyaan terbuka yang membutuhkan ketrampilan berpikir tingkat tinggi, dan komentar yang memperluas pemahaman anakanak. Memberikan pertanyaan yang berhubungan dengan gambar yang disajikan dalam buku cerita mendorong anak untuk mudah memahami isi cerita tersebut (Strasser, Larraín, dan Lissi, 2013). Tanya jawab dan umpan balik memang lebih sering terjadi ketika dilakukan pengamatan sehingga secara otomatis juga meningkatkan konsentrasi dan minat anak dalam setiap alur cerita.

Membaca buku cerita merupakan kegiatan yang menarik bagi anak usia dini dan diyakini dapat meningkatkan produksi kosakata anak, terlebih apabila buku cerita dikemas dengan ilustrasi gambar yang menarik dan tanpa teks. Wordless picture book sering digunakan orang tua maupun guru untuk meningkatkan produksi kosakata anak. Pengembangan bahasa anak usia dini menggunakan buku elektronik dapat memotivasi dan menghibur mereka (Shamir dan Korat, 2014). Tingkat pengetahuan kosakata dengan penggunaan electronic wordless picture book menunjukkan hasil yang baik. Nilai positif buku elektronik di lingkungan keaksaraan awal, yaitu (1) memberi keuntungan bagi anak dengan lebih banyak memperoleh kata-kata, (2) menciptakan pilihan bahan bacaan di lingkungan literasi awal, dan (3) menyediakan pembelajaran kosakata (Roskos, dkk., 2016).

Kedua jenis buku memiliki fungsi masing-masing meskipun hasil penelitian menunjukkan bahwa electronic wordless picture book lebih efektif meningkatkan produksi kosakata anak usia dini. Meskipun demikian, tidak semua sekolah dapat mengaplikasikan hasil penemuan ini dikarenakan keterbatasan sarana atau fasilitas yang ada. Keuntungan bagi pengguna printed wordless picture book adalah guru tidak harus selalu mengawasi anak-anak ketika membaca. Setelah kegiatan membaca bersama dan diskusi dilakukan, anak-anak dapat membuka kembali printed wordless picture book. Hal ini tidak dapat dilakukan ketika sekolah menggunakan electronic wordless picture book yang mengharuskan guru untuk selalu mengawasi anak ketika menggunakan.

Implikasi praktis dari penelitian ini adalah guru dapat memanfaatkan kemajuan teknologi sebagai salah satu media untuk menstimulasi perkembangan bahasa anak. Suasana yang inovatif dibutuhkan anak untuk mengurangi rasa jenuh. Lebih lanjut, anak usia dini sangat antusias menggunakan barang elektronik. Mereka akan mendapatkan banyak manfaat positif apabila diarahkan penggunaannya dengan benar. Ketika menggunakan buku cerita bergambar tanpa teks elektronik, guru dapat membangun cerita bersama dengan murid dengan melakukan interaksi tanya jawab, menata tempat duduk anak sehingga semua anak dapat melihat buku elektronik yang disajikan menggunakan layar laptop/komputer/ LCD, dan memberikan kesempatan kepada setiap anak untuk mengeluarkan pendapatnya. Dengan cara ini, anak cenderung termotivasi untuk mencari tahu kelanjutan ceritanya. Membaca buku cerita dapat mendorong pertumbuhan bahasa anak, keaksaraan, dan kemampuan membaca anak (Saracho, 2016).

\section{PENUTUP}

Hasil penelitian ini menunjukkan bahwa menggunakan electronic wordless picture book lebih efektif meningkatkan produksi kosa kata anak yang dilihat dari jumlah kata per halaman dan jumlah jenis kata (kata benda, kata kerja, kata sifat, kata keterangan, dan kata tanya). Membaca buku secara klasikal atau kelompok harus menjadi kegiatan yang direncanakan. Guru dituntut menetapkan tujuan tentang jenis keterampilan bahasa yang ingin distimulus dan diukur serta dan memilih media yang bervariasi. Printed wordless picture book mungkin lebih cocok digunakan ketika anak melakukan aktivitas ini tanpa adanya pengawasan dari guru, sementara electronic wordless picture book bisa dipilih untuk memberikan variasi agar pembelajaran tidak terkesan monoton. 
Sesuai dengan perkembangan teknologi yang semakin mudah, hasil penelitian memberikan manfaat menggunakan electronic wordless picture book. Ketika para guru mengajak anak membaca sebuah electronic wordless picture book, mereka cenderung membangun cerita bersama dengan murid dan anak cenderung termotivasi untuk mencari tahu kelanjutan ceritanya.

\section{DAFTAR PUSTAKA}

Chaparro-Moreno, L. J., Reali, F., \& MaldonadoCarreño, C. 2017. Wordless Picture Books Boost Preschoolers' Language Production During Shared Reading. Early Childhood Research Quarterly, 40: 52-62.

Ciampa, K. 2012. Electronic Storybooks: A Constructivist Approach to Improving Reading Motivation in Grade 1 Students. Canadian Journal Of Education, 35 (4): 92-136.

Conrad, N., and Tracy, B. 2016. The Literacy Skills and Motivation to Read of Children Enrolled in Title I : A Comparison of Electronic and Print Nonfiction Books. Early Childhood Education Journal, 44(5): 527-536. doi:10.1007/ s 10643015-0735-0.

Evans, M. A., Nowak, S., Burek, B., andWilloughby, D. 2017. The Effect of Alphabet eBooks and Paper Books on Preschoolers' Behavior: An Analysis Over Repeated Readings. Early Childhood Research Quarterly, 40: 1-12.

Korat, O. and Blau, H. 2010. Repeated Reading of CD-ROM Storybook as a Support for Emergent Literacy: A Developmental Perspective in Two SES Groups. Journal Of Educational Computing Research, 43(4): 445-466. doi:10.2190/ EC.43.4.b

Korat, O., \& Shamir, A. 2012. Direct and Indirect Teaching: Using E-Books for Supporting Vocabulary, Word Reading, and Story Comprehension for Young Children. Journal Of Educational Computing Research, 46(2): 135-152.

Matthew, K. 1997. A Comparis on of the Influence of Interactive CD-ROM Storybooks and Traditional Print Storybooks on Reading Comprehension. Journal of Research on Computing in Education, 29 (3): 263-275. doi:10.1080/08886504.1997.10782198

Newton, D.P. 1992. Pictures in Books for Children at

\section{UCAPAN TERIMA KASIH}

Penulis menyampaikan ucapan terima kasih kepada mitra bestari (reviewers) yang telah memberikan saran, kritik, dan rekomendasi untuk perbaikan artikel ini. Ucapan terima kasih juga disampaikan kepada guru dan murid yang telah berpartisipasi dalam pelaksanaan penelitian ini.

Key Stage 1: an analysis, Educational Studies, 18 (3): 253-265, doi: 0.1080/0305569920180301

Prasetya, D. D. and Tsukasa, H. 2018. Design of Multimedia-based Digital Storybooks for Preschool Education. International Journal Of Emerging Technologies In Learning, 13 (2):211-225. doi: 10.3991/ijet.v 13i02.8188

Saracho, O. N. 2016. Parents' Shared Storybook Reading: Learning to Read, Early Child Development and Care, 187 (3-4): 554-567. doi: 10.1080/03004430.2016.1261514

Shamir, A., and Korat, O. 2014. Developing an Educational E-Book for Fostering Kindergarten Children $\hat{a} €^{\mathrm{TM}} \mathrm{s}$ Emergent Literacy Developing an Educational E-Book for Fostering Kindergarten Children' s Emergent Literacy. Interdisciplinary Journal of Practice, 24 (2): 37-41. doi:0.1300/J025v 24n 01 .

Strasser, K., Larraín, A., and Lissi, M.R. 2013. Effects of Storybook Reading Style on Comprehension: The Role of Word Elaboration and Coherence Questions. Early Education and Development, 24 (5): 616-639, doi: 10.1080/10409289.2012.715570

Torr, J., and Clugston, L. 1999. A comparison Between Informational and Narrative Picture Books As a Context for Reasoning Between Caregivers and 4-Year-Old Children. Early Child Development and Care, 159 (1): 25-41.

Whorrall, J. and Cabell, S. 2016. Supporting Children's Oral Language Development in the Preschool Clas sroom. Early Childhood Education Journal, 44 (4): 335-341. doi:10.1007/s 10643015-0719-0

Widodo. 2016. Bimbingan Teknik bagi Petugas Pengelola Perpustakaan Sekolah. (online). https://library.uns .ac.id/wp-content/uploads/2016/04/EBOOK.pdf, diakses: 1 Agustus 2018 